Savunma Bilimleri Dergisi

The Journal of Defense Sciences

Kasim / November 2021, Say1/Issue 40.

ISSN (Bas111) : 1303-6831 ISSN (Online): 2148-1776

\title{
The Statistical Analysis of Air Crash Investigations from 1918 to 2019
}

\author{
Ümit Deniz GÖKER* ${ }^{*}$, Mesut YAZICI ${ }^{* *}$, Gökhan BALCI ${ }^{* * *}$, \\ Özge KÖKSAL ${ }^{* * * *}$, Hakan Eren ŞENGELEN ${ }^{* * * * *}$
}

\begin{abstract}
Air transportation is one of the most preferred types of transportation for many reasons. However, to minimize the risk of accidents with developing technology, investigations and studies are carried out by many organizations. While the main causes of accidents in the first years of aviation were due to mechanical reasons, accidents caused by mechanical reasons have been replaced by an increase in the number of aircraft accidents caused by human-induced errors which depend on the increasing manpower with the developing technology. Nowadays, "Aviation" has become a high level of technical, administrative, and even technological operations. This was made possible by the introduction and production of larger and faster aircraft, which largely includes advanced information management technologies. From an industrial point of view, the fact that aircraft can carry people, cargo, mail, and similar at a more affordable price and in a shorter time has made aviation an important sectoral value. Competition has increased with the increase of aviation companies; therefore, businesses that tend to give overload to

* Doç. Dr., İstanbul Ayvansaray Üniversitesi., İISBF, Havacılık Yönetimi Böl., umitdenizgoker@ayvansaray.edu.tr, ORCID: 0000-0001-9985-5735.

** Harbiyeli Öğrenci, Millî Savunma Üniversitesi, Hava Harp Okulu, Havacılık ve Uzay Müh. Böl., 2511yazici@harbiyeli.hho.edu.tr, ORCID: 0000-0002-2539-7433.

*** Harbiyeli Öğrenci, Millî Savunma Üniversitesi, Hava Harp Okulu, Havacılık ve Uzay Müh. Böl., 2512balci@harbiyeli.hho.edu.tr, ORCID: 0000-0003-2324-0077.

**** Öğr. Gör., Millî Savunma Üniversitesi, Hava Harp Okulu, Temel Bil. Böl., okoksal4@ hho.edu.tr, ORCID: 0000-0002-4800-0611.

***** Arş. Gör., İstanbul Esenyurt Üniversitesi, İYBF, İşletme Böl., hakansengelen@esenyurt.edu.tr, ORCID: 0000-0002-2079-4720.
\end{abstract}

Geliş Tarihi/Received: 23.10 .2019

Kabul Tarihi/Accepted: 27.05.2021

Araştırma Makalesi/Research Article DOI:10.17134/khosbd.1000317 
employees for the sake of gaining more can cause aircraft accidents. Increased traffic volume and demand for air transportation mean risks and increases in air crashes. In this study, human-induced errors and mechanical system errors, which cause air crashes are mentioned and the statistical analysis of air crashes between the years 1918-2019 is examined.

Keywords: Aviation Management, Aviation Psychology, Mechanical System Errors, Air Crash Reports.

\section{8-2019 Yılları Arasındaki Uçak Kaza Raporlarının İstatistiksel Analizi}

\section{$\ddot{O} z$}

Havayolu taşımacılığı birçok sebepten dolayı en çok tercih edilen ulaşım türlerinden biridir. Buna karşın gelişen teknoloji ile birlikte kaza riskini en aza indirmek için birçok kuruluş tarafindan çalışmalar ve araştırmalar yürütülmektedir. Havacılı̆̆ın ilk yıllarında meydana gelen kazaların esas sebepleri mekanik nedenlerden kaynaklanırken; gelişen teknoloji ile birlikte mekanik nedenlerden kaynaklanan kazalar yerini artan insan gücünün sebep olduğu insan kaynaklı hatalardan meydana gelen uçak kazalarının sayısında artışa bırakmıştır. Günümüzde, "Havacllık" yüksek düzeyde teknik, idari ve hatta teknolojik operasyonlara dönüşmüştür. Bu durum büyük ölçüde gelişmiş bilgi yönetimi teknolojilerini içeren daha büyük ve daha hızlı uçakların tanıtımı ve üretimi ile mümkün olmuştur. Endüstriyel bakış açısına göre uçağın insanları, kargoları, postalart ve benzerlerini daha uygun bir fiyata ve daha kisa sürede taşlyabilmesi havacılı̆̆ önemli bir sektörel değer haline getirmiştir. Havacılık şirketlerinin artmastyla rekabet artmıştır, böylece işletmelerin daha fazla kazanma uğruna çalışanlara aşırı yük verme eğiliminde olmaları uçak kazalarına neden olabilmektedir. Artan trafik hacmi ve hava taşımacılı̆̆ına olan talebin artmasl, hava kazalarında riskler ve artışlar anlamına gelir. Bu çalışmada, uçak kazalarınin nedenlerinden olan insan kaynakl hatalar ve mekanik hatalardan bahsedilmiş ve 1918-2019 yılları arasındaki uçak kazalarının istatistiksel analizi yapılmıştır.

Anahtar Kelimeler: Havacılık Yönetimi, Havacılık Psikolojisi, Mekanik Sistem Hataları, Uçak Kaza Raporları. 


\section{Introduction}

Aviation's ability to provide fast and reliable services by reducing time independent of geographical barriers compared to alternative transportations and increasing accessibility around the world has enabled aviation to be perceived as a more convenient and popular transportation method. Air traffic control is always marked by teamwork and requests are also met by the teams. Due to the increase in traffic volume, the installation of new technologies will not be appropriate. It will be necessary to develop team structures and initiate optimization programs (Riedle, 2006).

Many problems in air traffic management have one thing in common. It is important to minimize the arrival time of the goods and passengers in the system. Operation management procedures in air traffic systems are often based on a "planning phase" and a "real-time". In the first, items are allocated according to capacity and other regulations. The second is based on the idea of pushing the elements in the system and therefore focuses on resolving conflicts that may occur later in the chain of operations (Lucertini, Smriglio and Telmon, 1997). Unfortunately, airlines have had excessive capacity since the use of large hulls in the early 1970s. Since then, many carriers have focused on the marketing concept, which stresses shaping services to meet consumer needs, rather than molding consumer needs to fit the available services. However, profit-focusedness has brought other problems (Wensveen, 2007). With the development of science and technology, the ratio of accidents every 100,000 flight hours has dramatically decreased. In the last 100 years, this ratio of serious accidents has decreased more than 350 times, and that civil airplane has also notably decreased, reaching two times every 100,000 flight hours (Wang, Xu, Wei and Chen, 2014).

Air transportation is one of the most preferred types of transportation for many reasons. However, to minimize the risk of accidents with developing technology, investigations and studies are carried out by many organizations. Human factors, technical reasons, meteorology, bird strikes, lightning strikes, etc. can be cited as the main causes of accidents in aviation. Accident reports show that the human factor accounts for $72-80 \%$ of all accidents in aviation. The main causes of accidents in the first years of aviation were due to mechanical, technical, and electronic reasons; however, with the developing technology, accidents caused by 
decreasing technical reasons have been replaced by human-induced errors (Çetingüç, 2016).

The design of an air traffic management system mainly focuses on the dynamic control of congestion problems. Performance evaluation and optimization are based on several key concepts: system capacity or throughput, progress time and/or ongoing work, efficiency and cost-effectiveness, flexibility, and complexity. In the current air transport network, airports are considered as important elements for defining the capacity of the global system. Aircraft flow management at the airport causes undesired delays and costs if it cannot make a certain number of take-off and landing during a certain period due to restrictions. Reasons for this limited capability include the rapid increase in customer demand, and the difficulty of increasing the capacity of the system by establishing new airport facilities or expanding existing ones, as well as being excluded from existing analytical and simulation tools (Lucertini, Smriglio and Telmon, 1997). Increasing the number of flights without making a good plan to cover these costs and surviving the competition leads to an increase in the number of aircraft accidents by employing airline personnel for more hours (Calderón, 2014).

A crisis is a sudden, unexpected, unusual, stressful, and traumatic event that develops as a result of emotional deterioration. When we enter the flight environment, we are forced by physical and physiological stresses such as hypoxia, pressure decompression, barotrauma, acceleration ( $\mathrm{G}$ forces), vestibular and visual illusions, cosmic radiation, vertigo, jet lag, shift lag, noise, vibration, fog, wind, rain, snow, cloud, cold, imaginary horizon starlights, ozone concentration, etc. Besides, the pilot's psychotic diseases, personality disorders, substance and alcohol abuse, antipsychotic drugs, suicidal tendencies, dysfunction drugs, epilepsy drugs, self-mutilation and killing attempts, neuroses, loss of consciousness, and neurological progressive diseases are classified as accidents caused by human defects due to personality traits (Çetingüç, 2016); industrialization, urbanization and technological developments also affect aviation enterprises (Bal and Okkay, 2019a). Cognitive and behavioral impairment leads to reduce problem-solving skills, helplessness and disorganization. Anxiety, fear, tension, confusion, and depression may develop. Cognitive (attention, memory, judgment, decision, focus, problem-solving), emotional (desperation, hopelessness, anger, crying, depression), 
behavioral (slowing down, loss of appetite, irritability), and psychophysiological (tremor, palpitation, nausea, sweating) crisis may occur (Çetingüç, 2016).

Pilots, aircraft maintenance technicians, air traffic controllers, and flight operation specialists responsible for every moment of flight are among those many people who directly contribute to the creation of airline transportation. In other words, the low-level performance of the human component within the system in communication, situational awareness, workload management, leadership, teamwork, decision-making, and stress management skills can lead to human errors and violations and thus low safety performance (Okkay, 2017).

Improved safety and capacity in the terminal area are the main aviation concerns. Weather is the most obvious factor in accidents and delays in the US (e.g. $33 \%$ of commercial carrier accidents, $27 \%$ of general aviation accidents, and $70 \%$ of serious delays in the US aviation system). For these reasons, the security focuses on the detection and prediction of rapidly changing convective weather conditions, icing, and fresh air turbulence. Therefore, efforts are being made to provide better information to pilots and operations center personnel (Evans, 2001). For this reason, the responsibility of the enterprises towards their employees constitutes an important dimension of social responsibility (Okkay, 2019a).

As a result of globalization, agencies are more affected by technological, political, economic, and socio-cultural changes all over the world. Today, organizations are faced with competition to reach and influence consumers along with political, economic, social, and technological dynamic forces that shape the way they work, perform, and behave. Aviation companies that try to survive can regulate more flights. More flights that are restless lead to an overload on pilots and can cause crashes due to fatigue. In direct proportion, crises cause psychological problems such as anxiety, fear, tension, loneliness, helplessness, unwillingness, inadequacy, and insecurity (Okkay, 2019b). Although attempts have been made to automate air traffic control and to replace control devices with machines or technical systems, airway personnel due to increasing competition and intense working conditions continue to experience psychological stress (Riedle, 2006). 
The most important factors that affect job performance are psychological factors. The fact that the employee's performance cannot be compensated, and discrimination at work, closely influences the work performance (Bal and Okkay, 2019b). Organizational stress leads to failure. It is caused by faults or breaches by frontline personnel such as ground personnel, pilots, and air traffic controllers, which have a direct impact on the safety of the aviation system and can result in a damaging outcome (Muller and Drax, 2014). The employees who do not receive the wages they deserve are adversely affected, and the psychology of the employee weakens the organizational bond and decreases the performance (Bal and Okkay, 2019c). When estimating hazards and planning controls, great care must be taken to estimate how often and how people make mistakes and how they interact with other components of the system. This requires an understanding of physical (eg. height, vision, strength), physiological (stress, fatigue, health), psychological (motivation, decision-making, risky attitudes), and psycho-social factors (personal financial issues, marital) (Stolzer, Halford and Goglia, 2008).

In mechanical defects, the sustainability of aviation activities depends on the level of safety performance they have. Monitoring and control of the weight and balance of an aircraft play a critical role in the safe and efficient operation of the aircraft. During this process, the operating weights of the aircraft and the passenger, cargo, and fuel loads must be determined within the weight and load distribution limits specified by the manufacturer and certified by the aviation authorities (Çetek et al., 2016). The lack of balance of an aircraft results in the loss of maneuverability and controllability. If the load distribution inside the aircraft is not uniform, the center of gravity may go outside the average aerodynamic veterinary. Incorrect loading of the aircraft on the longitudinal axis causes problems in the airport or flight phases and some fatal accidents. The fuel that the aircraft used is also important. The consumption and transfer of fuel inside the tanks in the wings must be carried out in proper order for safe transportation.

When we look at the accidents in the airport, 25-knot lateral wind, heavy snowfall, fog, the presence of flocks in the vicinity, or the presence of a sharp metal strip that fall from the aircraft during a previous landing on the runway are the examples of potential hazards (Çetek et al., 2016). Dangerous substances such as explosives, gases, flammable liquids, flammable solids, oxidizing agents and organic peroxides, toxic and infectious substances, abrasives, and other dangerous 
substances should not be taken to the aircraft or if they are taken, they must be placed by following certain standards and in order within the aircraft (Yalçınkaya et al., 2016).

According to the Swiss-Cheese Model developed by Prof. James Reason, the cause of accidents is due to the consecutive violations of multi-system defense. These violations can be triggered by many factors, such as hardware failures or operational failures. In addition to this, in the Swiss-Cheese Model, all accidents are caused by a combination of both "active" and "hidden" errors. Errors or violations that show immediate effect are defined as "active errors". These errors are usually caused by leading personnel such as pilots, air traffic controllers, and aircraft maintenance technicians. "Hidden errors" are those errors that have been concealed (hidden) due to a transaction or decision taken much earlier than accidents. Such errors are often caused by regulatory authorities and decisionmakers (Uslu and Dönmez, 2016).

In terms of flight phases in civil aviation, accidents occur at take-off, cruise, and landing. This classification is divided into loading, unloading, towing, parking, waiting, taxiing, first climbing, climbing, descending, approaching, and final approaching. According to the statistics made by The International Civil Aviation Organization (ICAO) between 1993 and 2013, almost 90\% of the accidents are observed during the take-off, ascending and descending phases, and landing stages of the flight. In civil aviation, accidents are classified as commercial flights, cargo flights, and vacant flights. According to ICAO surveys, commercial aircraft have the highest rate of accidents with $79 \%$ in this classification. Accidents caused by commercial aircraft are also classified according to general aircraft engine types as turbojet and turboprop. From the 103 accident statistics of ICAO between 2011-2013 depending on the engine type, the accident rate is 54\% in turbojet engines and 46\% in turboprop engines (Uslu and Dönmez, 2016).

This study includes a detailed statistical analysis of all mechanical and human-related aircraft accidents involving death from the beginning of 1918 to the end of 2018. Besides, aircraft crashes due to war are not included in the analysis. In our study, security-threatening initiatives such as hijacking, cyber-attack, sabotage, and also meteorological accidents are also excluded. 


\section{Basic Analysis Results}

In this study, we classified and analyzed 3765 air crash investigations involving the death from the beginning of 1918 to the end of 2019.

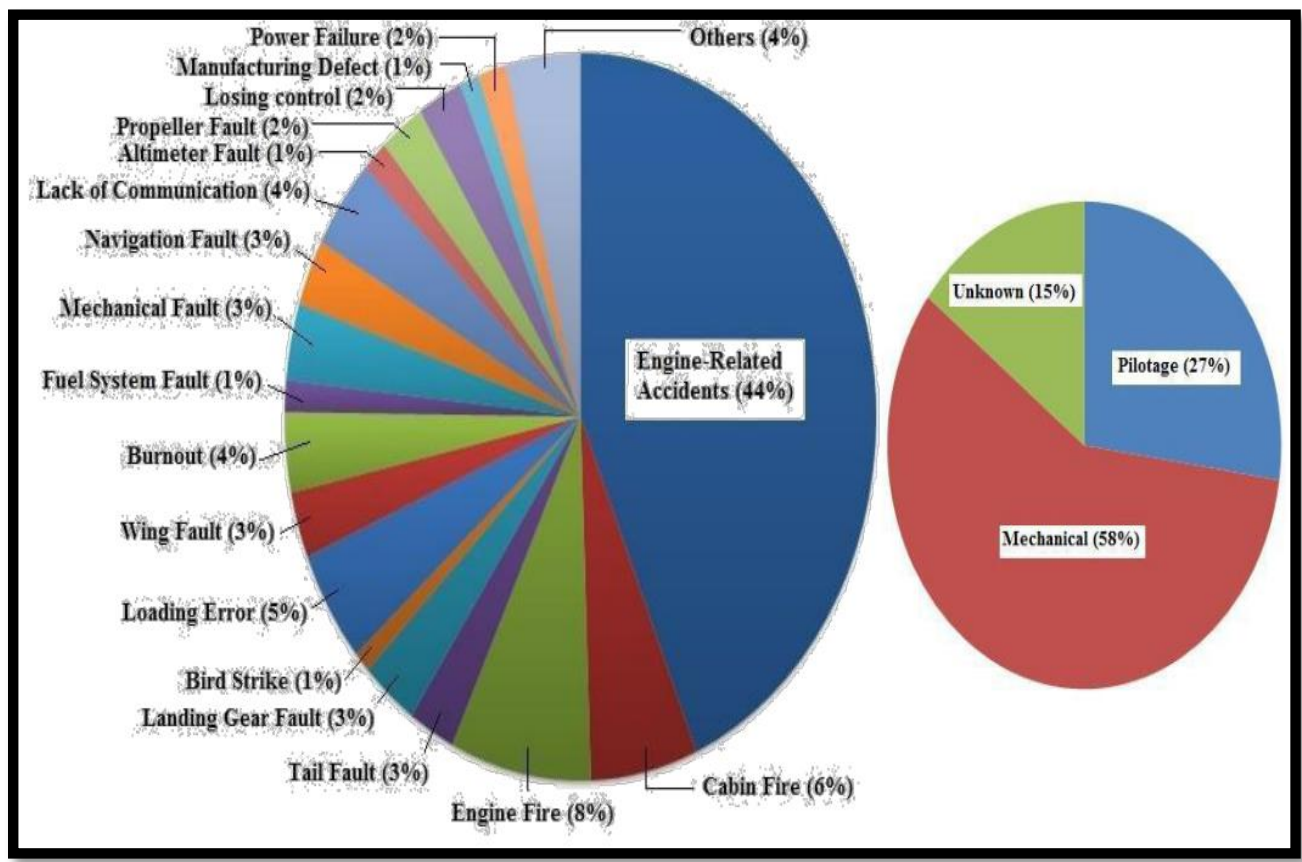

Figure 1. The Percentage Distribution of Accidents Due to System Errors (Left).

The Percentage Distribution of General Causes of Aircraft Accidents between 1918-2019 (Right).

This accident database includes all civil and commercial aviation accidents of scheduled and non-scheduled passenger airliners worldwide, which resulted in a fatality (including all U.S. Part 121 and Part 135 fatal accidents) and all cargo, positioning, ferry and test flight fatal accidents except military transport accidents and commercial and military helicopter accidents. We first found the percentage distribution of accidents due to system errors and classified air crashes as pilotage, mechanical and unknown as seen in Pie Charts in Figure 1. 


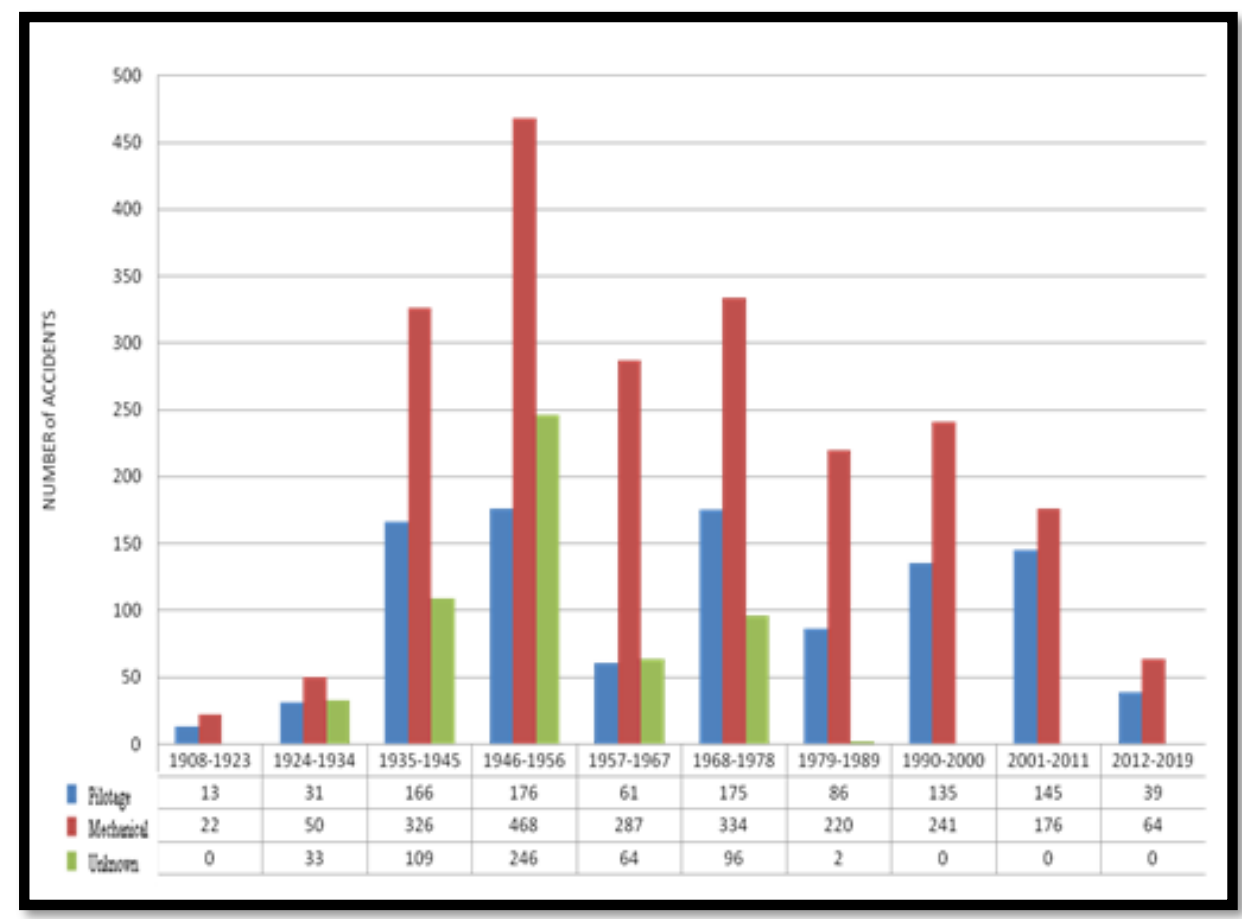

Figure 2. The Classification of General Causes of Aircraft Accidents According to 10-Yearly Intervals.

Air crash investigation data were taken, classified, and analyzed from the pages http://www.planecrashinfo.com/database.htm and https://www.ntsb.gov/ _layouts/ntsb.aviation/index.aspx. Afterwards, we classified the general causes of aircraft accidents according to 10-yearly intervals as shown in Figure 2. In Figure 3 , we classified the mechanical system errors according to 10 -yearly intervals. On the left-hand side of Bar Plots in Figures 2 and 3, the number of accidents is given while the general causes of accidents and mechanical system errors are determined at the abscissa coordinate, respectively. 


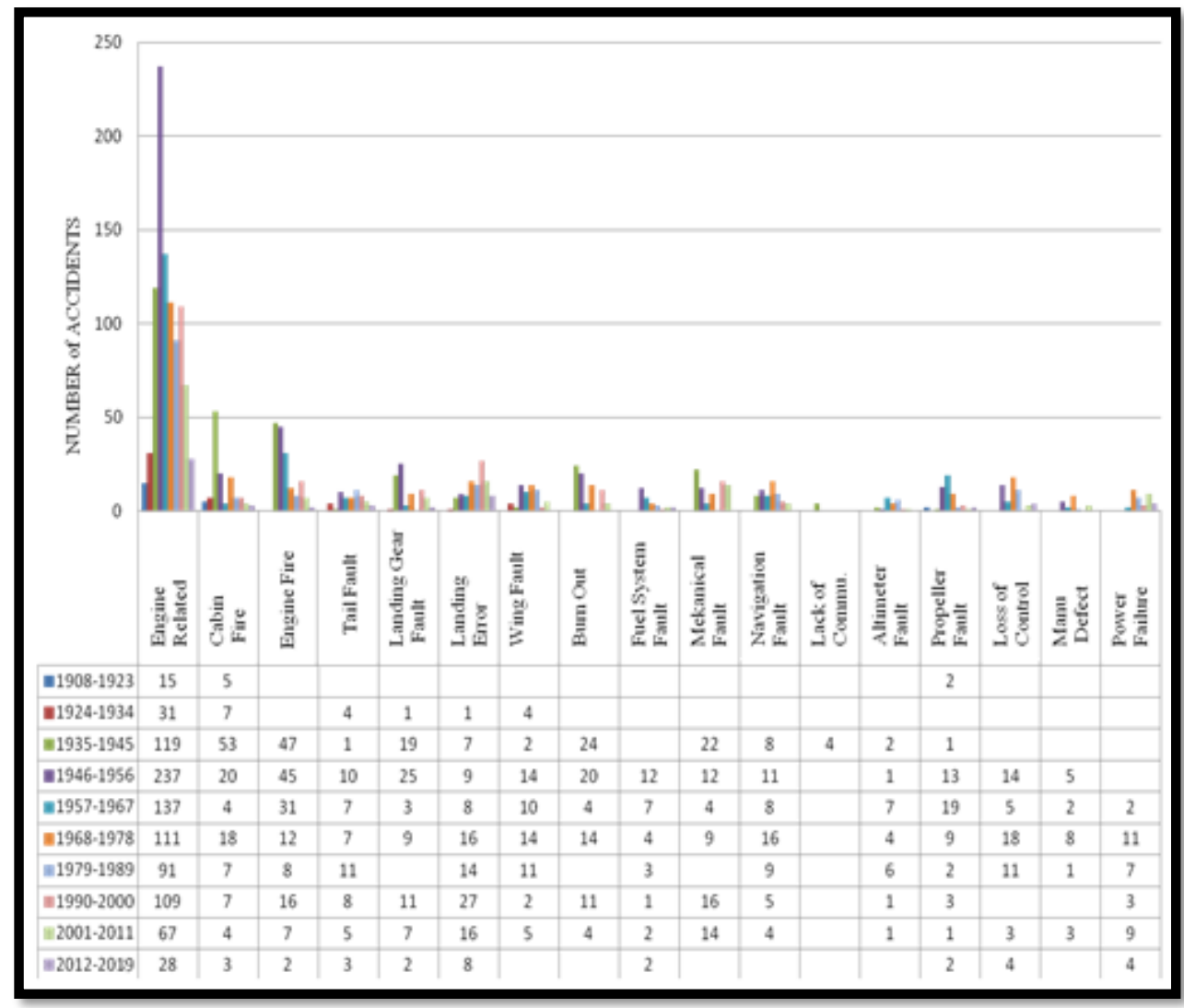

Figure 3. The Classification of Mechanical System Errors According to 10-Yearly Intervals.

\section{Annual Time Series Analysis with "R" Programming}

The data used in this study were the aircraft accidents caused by humanrelated and mechanical reasons that occurred between 1918-2019. This study aimed to analyze the time series of aircraft accidents according to years, to determine the appropriate time series model, and to make predictions for future years. Besides, considering the locations of the accidents, it was divided into four climate zones and an appropriate time series model has been tried to determine for the accidents occurring in each zone. "R 4.0.1" and "R Studio" were used while analyzing the time series of the data set for the relevant years. Time series packages were loaded into the $\mathrm{R}$ programming language and the analysis was 
carried out using these packages. Besides, "fpp2" and "tseries" packages were used while estimating the time series.

Time-series methods are based on analyzing the historical data of an event and making future predictions by revealing certain trends (Atalay, Tortum and Gökdağ, 2012). Therefore, the basic assumption in obtaining a prediction model with time series analysis is that the variable values were examined depending on the past time series of observational values. In this study, the Box-Jenkins method, one of the time series analysis methods, is used.

\subsection{The Components of Time Series Analysis}

A time series consists of the trend, seasonal changes, cyclical fluctuations (conjuncture), and random changes (error term):

a. Trend: It is the general trend of a variable observed over time in the form of an increase or decrease in the long period.

b. Seasonal Changes: It is expressed as the course of the changes completed within 1 year and repeated yearly.

c. Cyclical Fluctuations (Conjuncture): These are fluctuations that occur in long periods compared to seasonal fluctuations.

d. Random Changes (Error Term): These are irregular changes in the time series and have no definable course.

\subsection{BOX-JENKINS (ARIMA) Method}

ARIMA (Autoregressive Integrated Moving Average) is also known as the Box-Jenkins approach. A "stochastic" modeling approach that can be used to calculate the probability of a future value lies between two specified limits. These models can be applied to stationary or stationarized series. The general representation of these models is $\operatorname{ARIMA}(p, d, q)$. Here, " $p$ " is the degree of the Autoregressive (AR) Model, " $q$ " is the degree of the Moving Average (MA) Model, and " $d$ " is the degree of the difference. 


\subsubsection{Autoregressive Model, $\mathrm{AR}(p)$}

In AR $(p)$ model, the current value of the series can be expressed as the finite value consisting of the linear sum of past values of the series and a random shock such as " $e$ " (Box, Jenkins, Reinsel and Ljung, 2009). In this model, $Z_{t}=f_{1} Z_{t-1}+f_{2} Z_{t-2}+\cdots+f_{p} Z_{t-p}+e_{t}$ and here, $f$ is the unknown autoregressive coefficient and $e$ is the error parameter.

\subsubsection{Moving Average Model, MA $(q)$}

If the delayed error value of the related series affects the error value of the current period, it can be said that the process is the moving average process. In the moving average process, there is a connection between the predictive value of the variables and the error value. In this model, $Z_{t}=\mu+e_{1}-\beta_{1} e_{t-1}-\beta_{2} e_{t-2}-$ $\cdots-\beta_{q} e_{t-q}$ and here, $\mu, \beta$ and $e$ correspond to a constant parameter, unknown coefficient, and weighted average of random residuals backwards, respectively.

\subsubsection{Autoregressive Moving Average Model, ARMA $(p, q)$}

The use of a small number of parameters in time series models is a very important principle. To realize this principle, in some cases, both autoregressive and moving average parameters are handled together (Cryer and Chan, 2008). In this model, $Z_{t}=f_{1} Z_{t-1}+f_{2} Z_{t-2}+\cdots+f_{p} Z_{t-p}+e_{t}+\mu+e_{1}-$ $\beta_{1} e_{t-1}-\beta_{2} e_{t-2}-\cdots-\beta_{q} e_{t-q}$. Here, $f$ and $e$ are the autoregressive coefficient of unknown terms and the weighted average of random residuals backwards, respectively.

\subsubsection{Autoregressive Integrated Moving Average Model,} $\operatorname{ARIMA}(p, d, q)$

ARIMA $(p, d, q)$ includes both $\operatorname{AR}(p)$ and MA $(q)$ processes that contain $d$-th order stationary. The general equation is given, $Z_{\mathrm{t}}=\left(1+f_{1}\right) Z_{t-1}+$ $\left(f_{2}-f_{1}\right) Z_{t-2}+\cdots+\left(f_{p}-f_{p-1}\right) Z_{t-p}-f_{p} Z_{t-p-1}+e_{1}-\beta_{1} e_{t-1}-\beta_{2} e_{t-2}-$ $\cdots-\beta_{q} e_{t-q}$.

\section{3. “R” Analysis Results}

In this analysis, firstly, the situation of aircraft accident data originated from human-related and mechanical reasons that occurred between 1918-2019 is 
given over the years. The time path graph is shown in Figure 4. From this graph, it can be seen that the first significant increase in aircraft accidents occurred between 1925-1930. It is observed that the most serious increases have been experienced with the coming of the 1940s and it has affected the distribution very seriously, as well. While 1948 attracted attention in terms of being the most accidental year with more than 200 aircraft crashes, it is seen that the accidents decreased significantly in the 2010s.

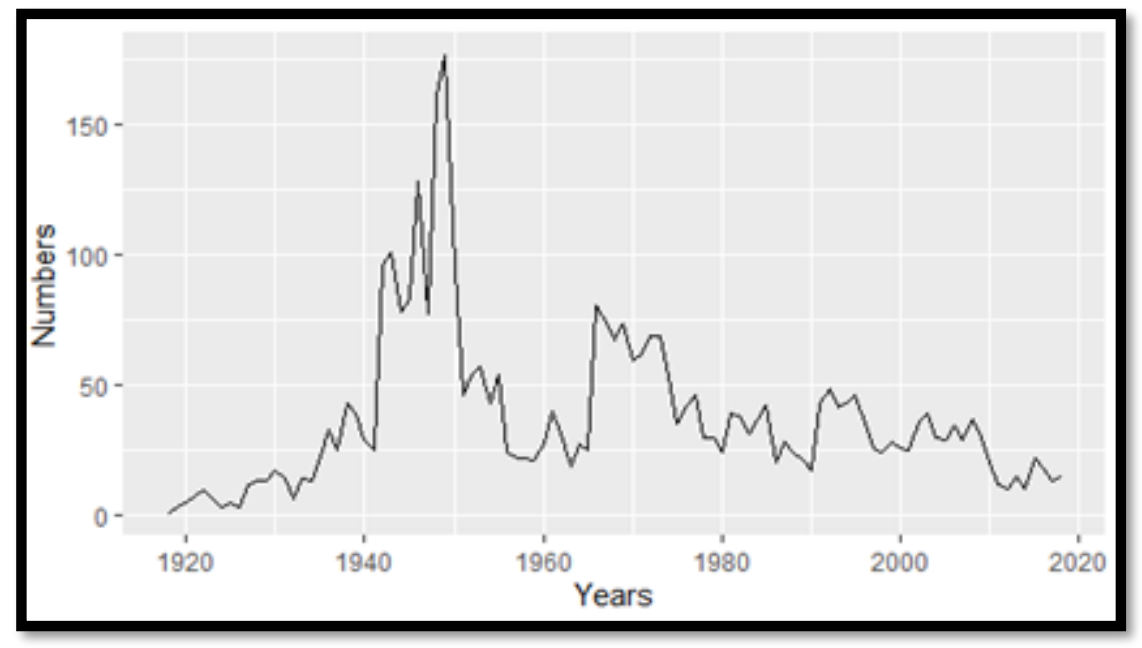

Figure 4. Aircraft Accidents According to the Years.

It can be seen that there are different accident numbers in some years and it does not move around the average stationery when Figure 4 is analyzed in terms of stationarity. To analyze this situation statistically, a unit root test was performed. When the literature is examined, the most frequently used unit root testing time series analysis and Box-Jenkins methods are Augmented Dickey-Fuller (ADF Test) and Dickey-Fuller (DF Test). However, the Augmented Dickey-Fuller test was preferred because it is the more advanced test. The test output is shown in Table 1(a). 
Table 1(a). ADF Test Results (Augmented Dickey-Fuller Test).

\section{Data: Data_ts}

Dickey-Fuller: -2.5086, Lag Order: 4, $p$-value: 0.3659

Alternative Hypothesis: Stationary

According to $\mathrm{ADF}$ unit root test results, since the $p$-value is greater than 0.05 , the zero hypotheses that say "Serie contains the unit root" could not be rejected. Therefore, it is seen that the series was not stationary. In addition to the logarithmic transformation, a difference operation was applied to stagnate the series and the movements of the data were randomized. When the unit root test of the newly created series was performed, it was revealed that it did not contain unit root and it was stationary in the first order. The test output is shown in Table 1(b). The aircraft accidents chart that changes by years were created for three different situations of the series as seen in Figure 5.

Table 1(b). ADF Test for the Serie that Taken of the First Difference and Logarithm.

Data: Data_Log_Diff

Dickey-Fuller: -6.8579, Lag Order: 4, $p$-value: 0.01

Alternative Hypothesis: Stationary

In addition to the logarithmic transformation, a difference operation was applied and the movements of the data were randomized, that is, it became stationary. After the series turned out to be stationary, the stage of determining the most suitable model was started. Firstly, an evaluation was made on the chart and it was aimed to give an idea about which models could be selected. When the AutoCorrelation Function and Partial Auto-Correlation Function graphs, which are shown in Figure 6 are evaluated together, it can be concluded that the "Data_Log_Diff" series contains both AR and MA. Significant prediction parameters, the significance of the model and Akaike (AIC) information criterion were evaluated together and the prediction model was decided. As a result, it is assumed that the model with the best results is ARIMA $(5,1,6)$, which has the least 
error coefficient (with the lowest AIC information criterion). The results of the installed model are given in Table 2.

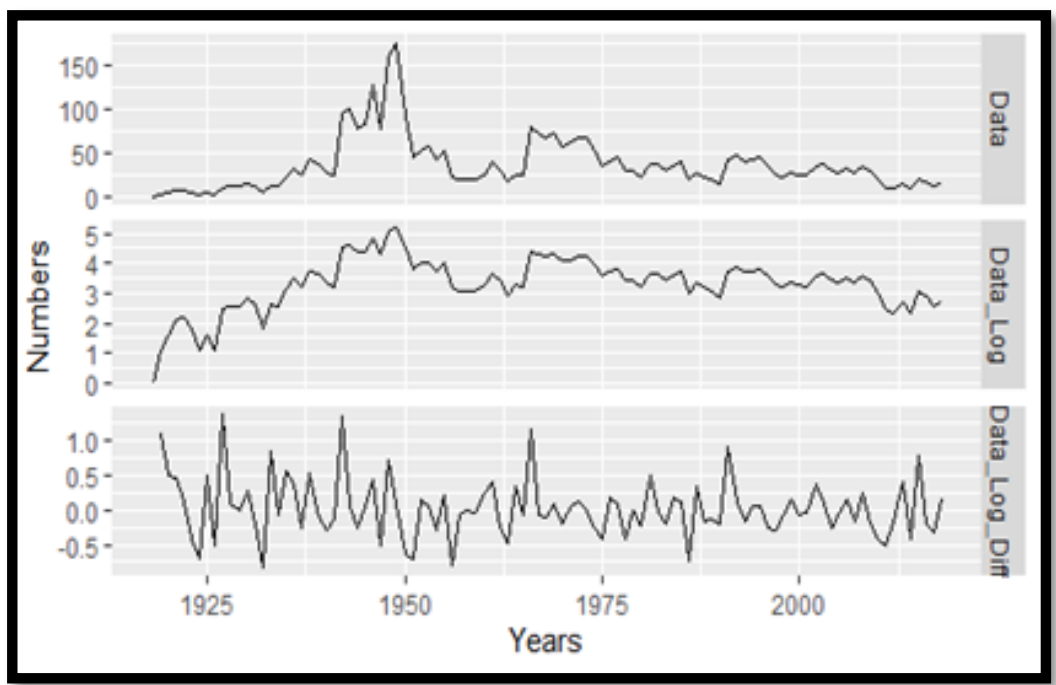

Figure 5. Aircraft Accidents According to the Years for Three Different Types of the Serie.

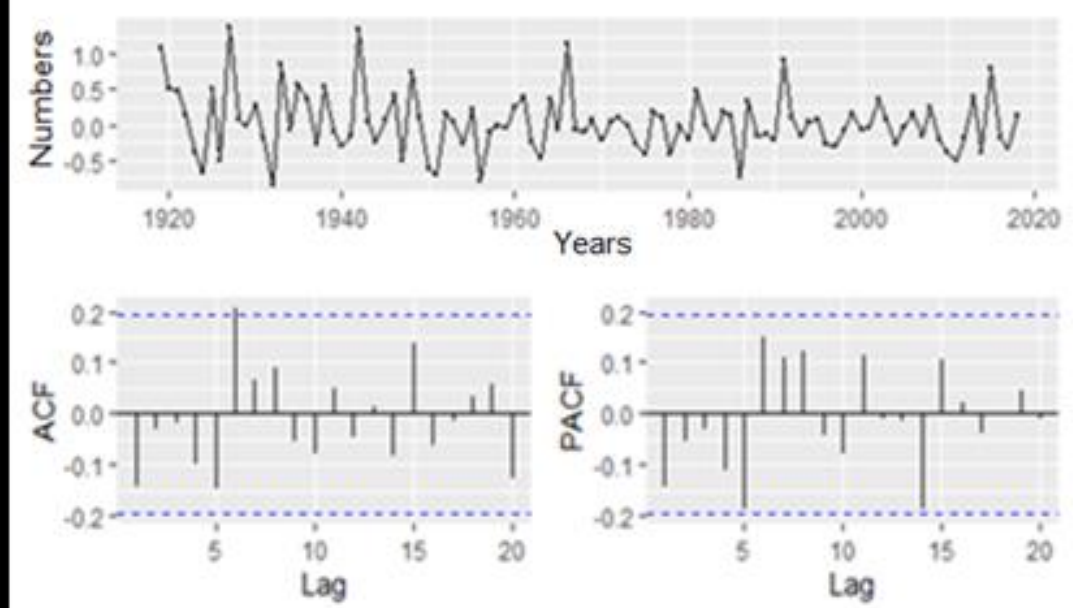

Figure 6. ACF and PACF Graphics. 
Table 2. ARIMA $(5,1,6)$ Model Results.

ARIMA $(5,1,6)$

Box Cox Transformation: Lambda $=0$

\begin{tabular}{cccccccc}
\hline \multicolumn{9}{c}{ Coefficients } \\
ar1 & ar2 & ar3 & ar4 & ar5 & ma1 & ma2 & ma3 \\
0.4151 & -0.6105 & -0.3318 & 0.0620 & -0.5956 & -0.6536 & 0.8010 & 0.1032 \\
s.e. & 0.3105 & 0.3796 & 0.2434 & 0.1988 & 0.2823 & 0.3871 & 0.4709 \\
0.2620 & & & & & & & \\
ma4 & ma5 & ma6 & & & & & \\
-0.2614 & 0.5982 & 0.0731 & & & & & \\
s.e. & 0.2675 & 0.1684 & & & & & \\
0.3636 & & & & & & & \\
\hline
\end{tabular}

Sigma $^{\wedge} 2$ Estimated as 0.1582: $\log$ Likehood $=46.87$

$\mathrm{AIC}=117.74 \quad \mathrm{AICc}=121.33 \quad \mathrm{BIC}=149$

In order to use the ARIMA model, the assumption that no residual autocorrelation was tested. Ljung-Box Test was used for this. As a result of the Ljung-Box test, the $p$-value is higher than the significance level of 0.05 (0.1302), "H_0: There is no autocorrelation in the residue" hypothesis was accepted. Table 3 and Figure 7 show the status of these residuals. It can be seen from the distribution graphics that the residuals of the ARIMA $(5,1,6)$ model show the normal distribution and do not have autocorrelation. Also, it is seen that all autocorrelations are within the limits in the autocorrelation graph (ACF) of the residues. In other words, the residuals of the model behave as White Noise that has a fixed mean and variance (Figure 7).

Table 3. Ljung-Box Test Results.

Data: Residuals from ARIMA $(5,1,6)$

$\mathrm{Q}^{*}=5.6449, \quad d f=3, \quad p$-value $=0.1302$ 


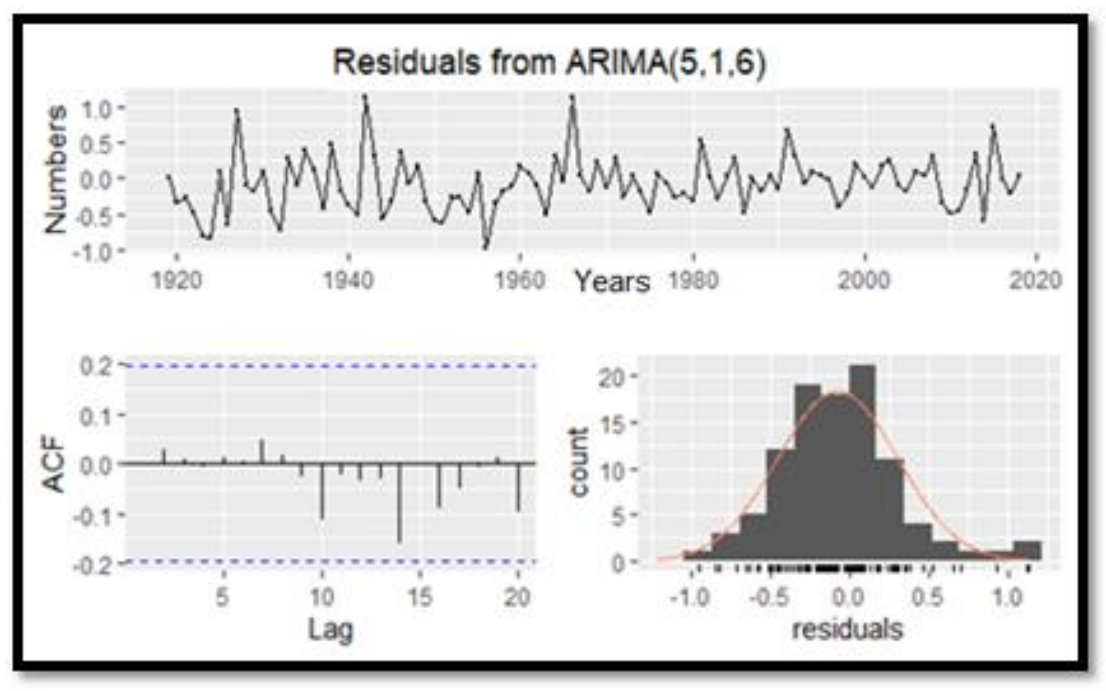

Figure 7. Correlation of Residuals in the Model.

After selecting the best ARIMA model and providing the assumption, the estimation was started. The representation of the ARIMA $(5,1,6)$ model is as follows:

$$
\begin{aligned}
\text { Data }_{t} & =0.0204+0.4151 \text { Data }_{t-1}-0.6105 \text { Data }_{t-2}-0.3318 \text { Data }_{t-3} \\
& +0.0620 \text { Data }_{t-4}-0.5956 \text { Data }_{t-5}+\varepsilon_{t}-0.6536 \varepsilon_{t-1} \\
& +0.8010 \varepsilon_{t-2}+0.1032 \varepsilon_{t-3}-0.2614 \varepsilon_{t-4}+0.5982 \varepsilon_{t-5} \\
& +0.0731 \varepsilon_{t-6}
\end{aligned}
$$

In order of the model to give a good estimation result, real values and estimated values were compared. For this, the data set was divided into two groups as training and testing, and the effectiveness of the model was evaluated. The years 1918-2000 and 2001-2019 were the sets as training and test, respectively. The values predicted by the model with the real data of 17 years are shown in Figure 8 . When the estimated numbers are analyzed, it is seen that the first 6-7 years forecast is similar to the original data and then continues with a certain value. The coming years have been estimated by the model. The 10-yearly period between 2020-2028 was estimated and the number of accidents was evaluated. Estimation results are given in Table 4. It is predicted that, as in the original accident numbers, there will be both an increasing and decreasing number of aircraft accidents over the years 
and the highest accident will occur in 2022 and 2023. It can be said that the deviation may be higher due to the density of the blue region from the linear prediction graph in Figure 9. When the number of accidents after 2010 was analyzed, it was seen that the estimation made by the ARIMA model was strong and the comments were statistically valid.

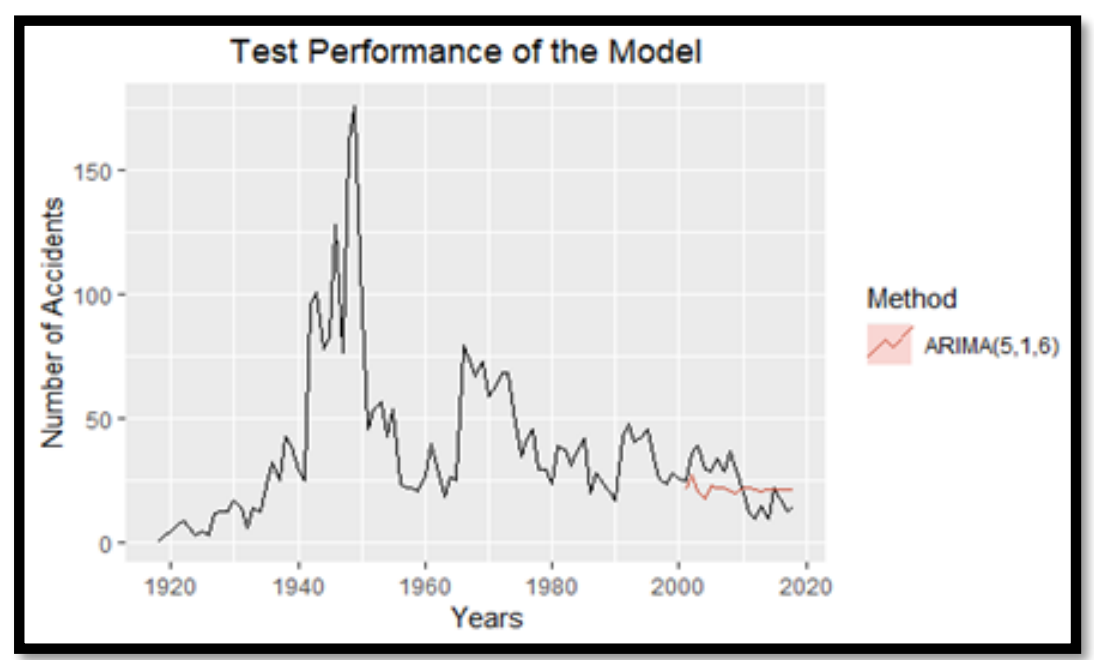

Figure 8. The Estimation Power of the ARIMA $(5,1,6)$ Model.

Table 4. 10-Yearly Predicted Values.

\begin{tabular}{cc}
\hline Years & Predicted Aircraft Accidents \\
\hline 2020 & $12.10995=12$ \\
2021 & $14.07390=14$ \\
2022 & $18.30307=18$ \\
2023 & $18.81120=19$ \\
2024 & $15.68381=16$ \\
2025 & $14.70657=15$ \\
2026 & $14.73587=15$ \\
2027 & $13.95615=14$ \\
2028 & $13.54333=14$ \\
\hline
\end{tabular}




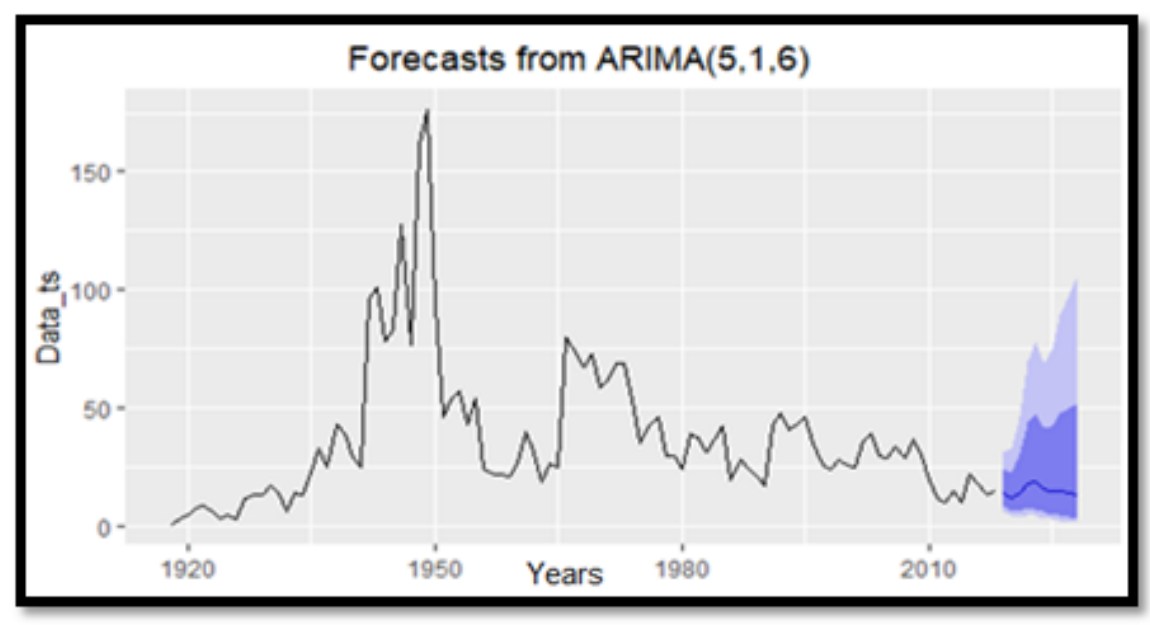

Figure 9. 10-Yearly Estimation with ARIMA $(5,1,6)$ Model.

After the estimation of general aircraft accidents was found, the data set was divided according to the zones where the accidents occurred and four main climate zones have been created. The four climate zones were defined based on the position of the Ferrel, Hardley, and Polar cells in the General Atmospheric Circulation to classify the location of the accidents (Mazon et al., 2018) and it's shown in Table 5. The ARIMA modeling steps were repeated for each zone and how convenient they were for estimation was examined as seen in Figure 10.

Table 5. Range of Latitudes for the Four Zones.

\begin{tabular}{ccc}
\hline Zone & Latitude Range $\left(^{\circ}\right)$ & Main Features \\
\hline 1 & \pm 12 & Equatorial Area \\
2 & $12-38$ (Both Hemispheres) & High-pressure, Low Altitudes \\
3 & $38-64$ (Both Hemispheres) & Low-pressure, Large-scale Polar Fronts \\
4 & $64-90$ (Both Hemispheres) & Polar Regions \\
\hline
\end{tabular}

When the time series analysis was made for four zones, it was seen that Zone 2 was separated from the others and gave meaningful results. Aircraft accidents in Zone 2 can be seen in Figure 10b. It is noteworthy that the higher number of accidents occurred with a significant difference between 1957-1958. 
Second, a significant increase was observed in 1975, and it was seen that there was less accident in the 1980s.

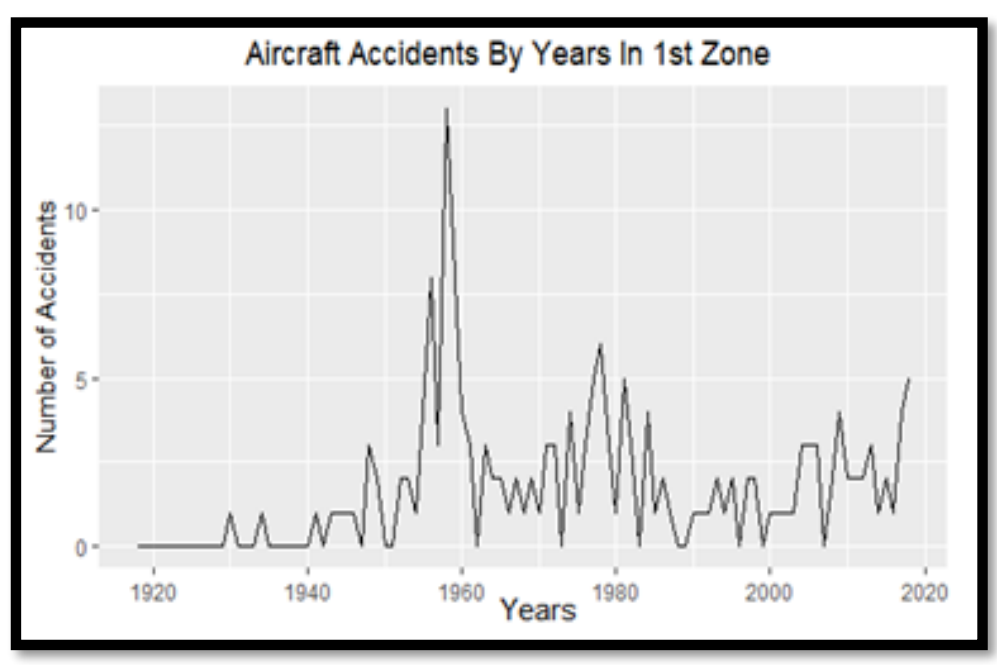

(a)

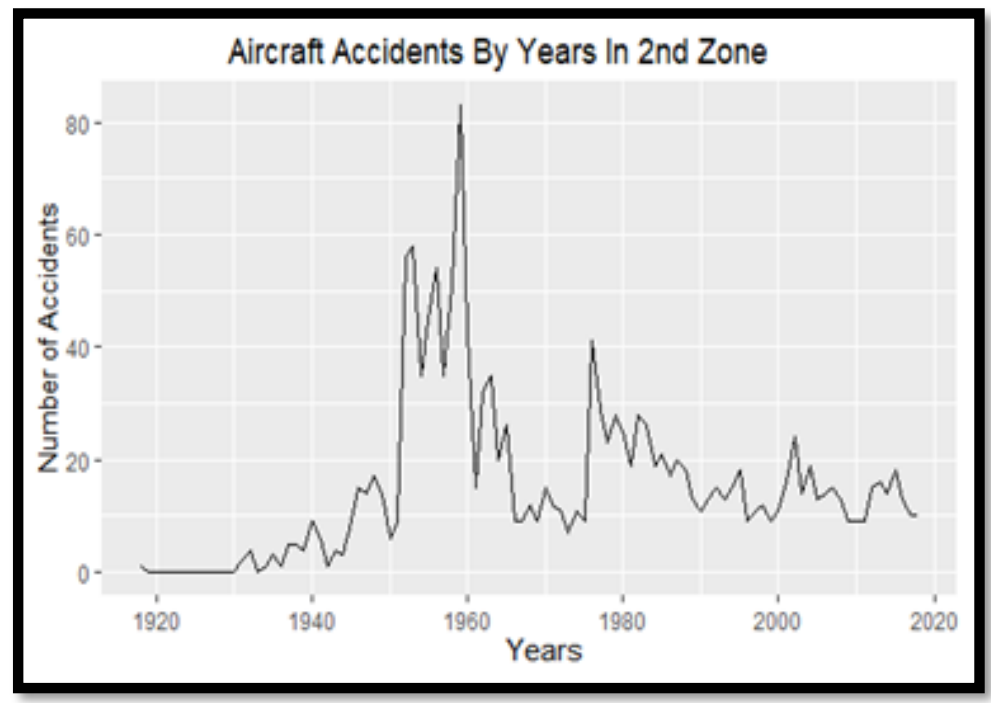

(b) 


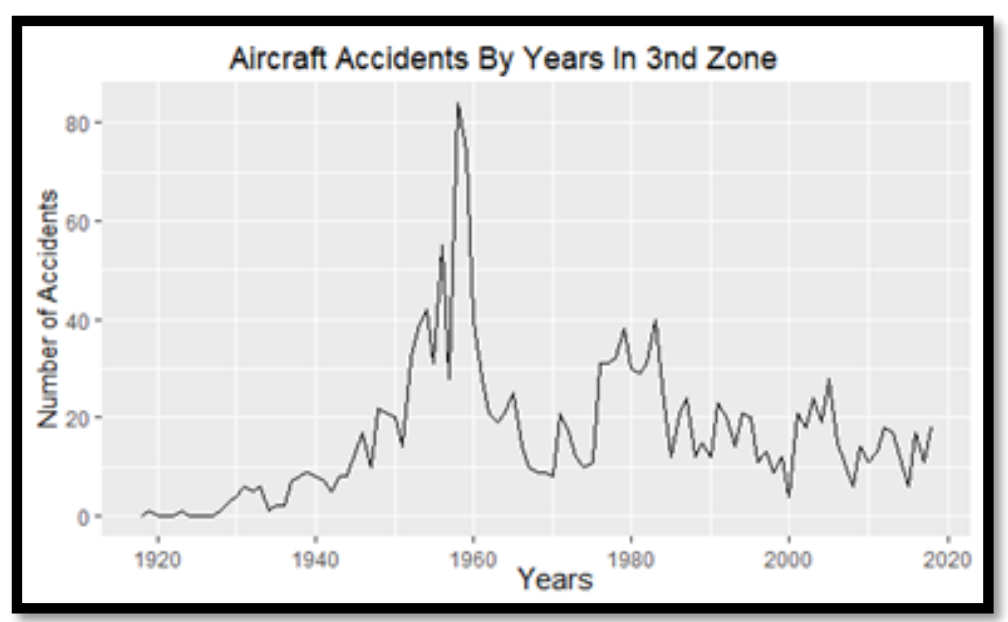

(c)

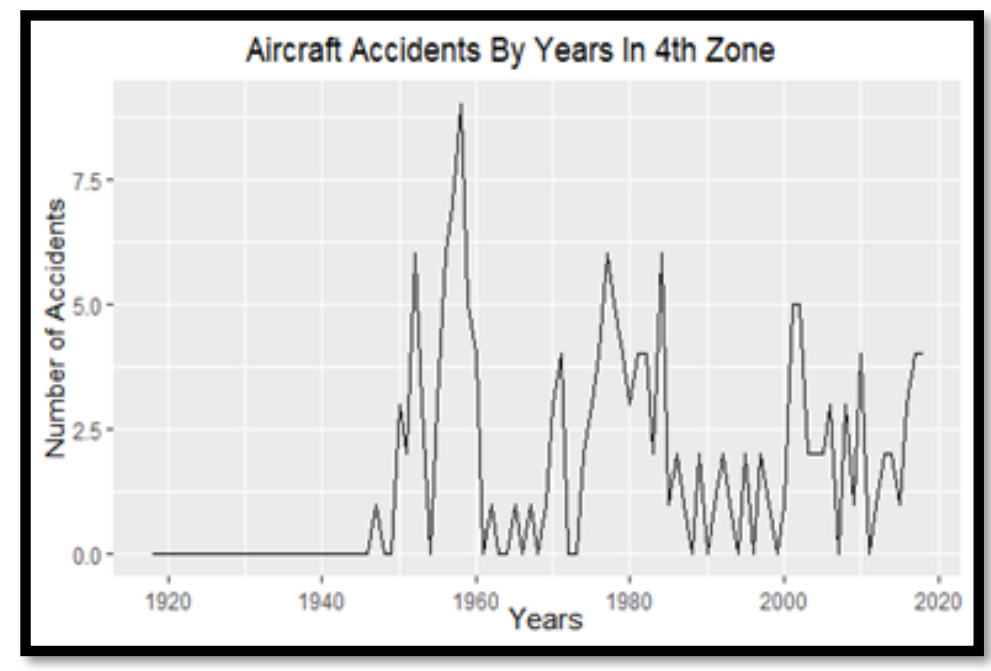

(d)

Figure 10. Aircraft Accidents According to the Years in the Four Zones.

As a result of the stability test, the unit root existence was determined and the series became stationary after the first difference was taken in Table 6 . The 
original values of the series and their values after taking the difference are given in Figure 11.

Table 6. The Results of ADF Unit Root Test.

Augmented Dickey-Fuller Test
Data: Data_ts
Dickey-Fuller: -2.0001, Lag Order: $4, p$-value: 0.5766
Alternative Hypothesis: Stationary
Augmented Dickey-Fuller Test
Data: ((Data_ts), 1)
Dickey-Fuller: -6.1567, Lag Order: $4, p$-value: 0.01
Alternative Hypothesis: Stationary

ACF and PACF graphics are shown in Figure 12, and the AR and MA effects can be seen. According to the AIC information criterion, the model with the lowest error was ARIMA $(10,1,2)$. Ljung-Box, which is a residue test, was made and there was no autocorrelation in the residues ( $p$-value: $0.5421>0.05)$, then estimation was started.

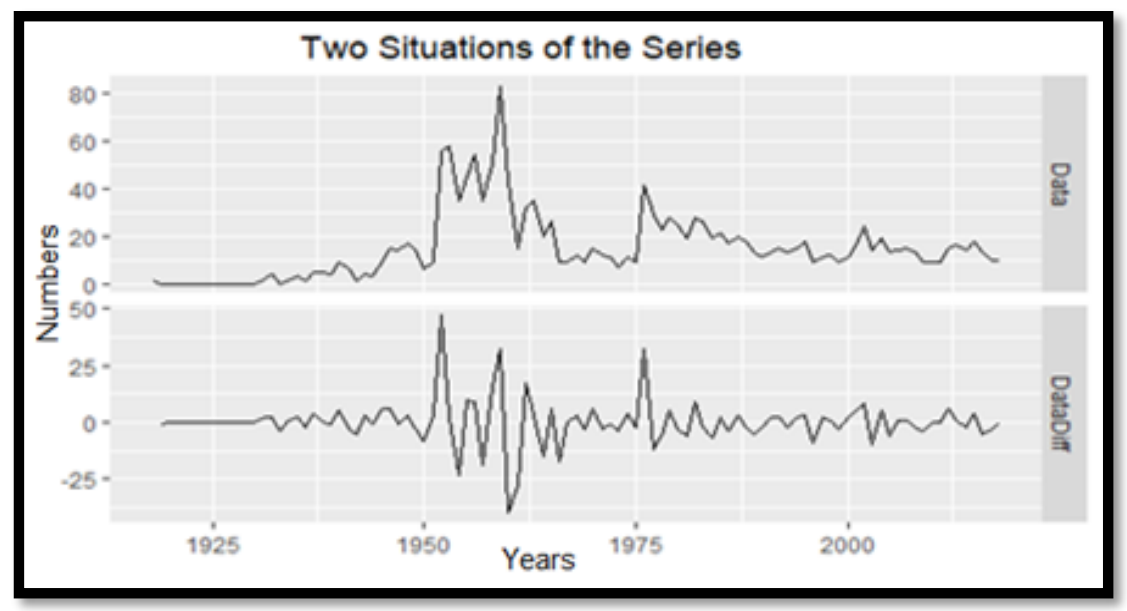

Figure 11. Aircraft Accidents According to the Years. 
According to the estimation results, aircraft accidents will decrease regularly in Zone 2 between the years 2020-2024, but they will increase again after 2022 (Figure 13).

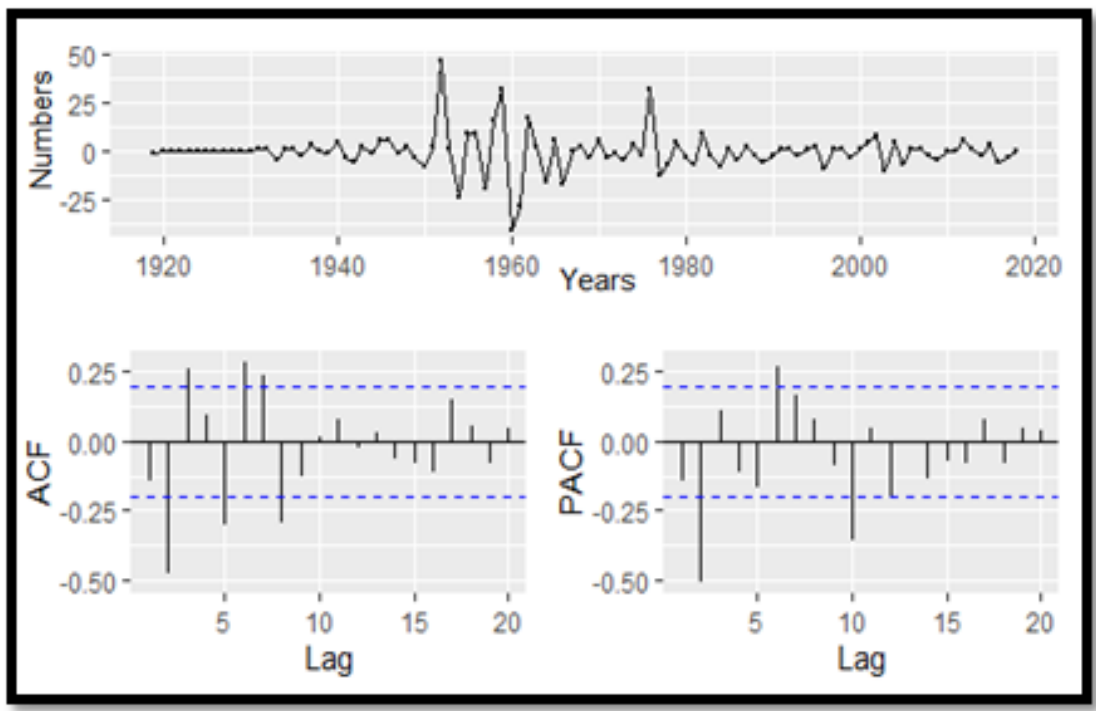

Figure 12. ACF ve PACF Graphics for Zone 2.

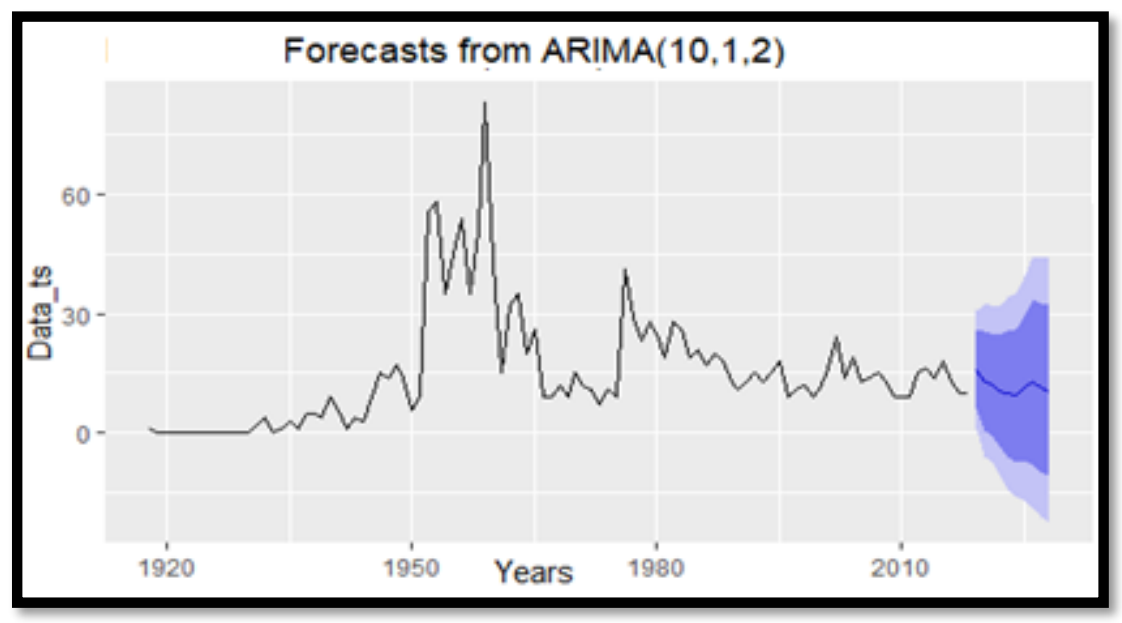

Figure 13. Estimated Accident Graphics for Zone 2. 
Ümit Deniz GÖKER, Mesut YAZICI, Gökhan BALCI, Özge KÖKSAL, Hakan Eren ŞENGELEN

\section{Discussions and Conclusions}

Aviation accidents create serious headlines and constitute a problem that affects the economic, social, psychological, and even political agenda. The mortality rate of aircraft passengers is heavy in terms of the cost and capacity of the plane crash, both spiritual and material (Doviak, Mazur and Zrnic, 1999). With the rapid development of civil aviation, there is an increasing emphasis on security. Almost $70 \%$ of aviation accidents are caused by operational errors (Sun, Ma, Li and Shen, 2014). It is clear that developing technology reduces the number of deaths in aircraft accidents. Although the number of flights at the beginning of the first years of commercial aviation was low, the number of accidents and fatalities was relatively high. Besides, the competition between different airlines in civil aviation has increased and this has affected the number of accidents inversely. Accordingly, in the 1950s Caravelle, Corvette, BAC 111 aircraft; in the mid-1960s, the presence of giant companies such as Airbus, Boeing, and Concorde have caused big accidents. In the early 1980s, a significant increase in the number of 3rd generation aircraft also affected the number of flights in direct proportion. Accordingly, the 3rd and 4th generation aircraft with the latest technology has been used in recent years while the 2nd generation aircraft have still been long-term aircraft (Uslu and Dönmez, 2016).

If we compare aircraft accidents according to accident situations of 1st, 2nd, 3rd, and 4th generation aircraft, it is observed that the rate of deaths in the usage period of the 2nd generation aircraft from 1994 to 2013 was at the highest level and it was approximately the same value between 1994-2004. The number of deaths of the 2nd generation aircraft in accidents between 2004 and 2013 has gradually increased and this increase has brought an end to the 2nd generation aircraft gradually. The number of deaths in the crashes of the 3rd generation aircraft as compared to the 2 nd generation aircraft is relatively less and has a fixed rate over the years. The most successful aircraft in this regard is the latest technology 4th generation aircraft (Uslu and Dönmez, 2016). When the history of aviation is examined, it is seen that the causes of accidents differ periodically. Therefore, the causes of accidents in aviation and the historical development of the concept of safety can be examined in three stages: (a) the period of technical factors (1900-1960); (b) the period of human factors (1970-1990); and (c) the period of organizational factors (1990-present). In the early 1970s, significant 
technological developments were seen with the introduction of jet engines, radar (both in the air and on the ground), autopilots, flight routers, advanced navigation and communication skills, and similar performance-enhancing technologies both in the air and on the ground. This has focused on team skills management (CRM), line-oriented flight training (LOFT), human-centered automation, and other interventions to human performance, as well as safety performance and human factors (Uslu and Dönmez, 2016).

In our study, we classified and analyzed 3765 air crash investigations involving death from the beginning of 1918 to the end of 2019. Air crash investigation data were taken, classified, and analyzed from the web pages: https://www.ntsb.gov/_layouts/ntsb.aviation/index.aspx and http://www. planecrashinfo.com/database.htm. Within the scope of this study, statistical analysis of all involving the death aircraft accidents caused by human and mechanical defects between 1918 and 2019 was carried out, and which kind of accidents occurred mainly, and the causes of these accidents were investigated approximately for 100 years, as well. We first found the percentage distribution of accidents due to system errors and classified air crashes as pilotage, mechanical and unknown as seen in Pie Charts in Figures 1(a) and 1(b), respectively. As can be seen from Figures 1(a) and 1(b), "Mechanical defects" are the most common causes of accidents, which is followed by "Pilotage errors". The distribution of the probability of these accidents according to the years has already been explained in the literature, however, in our study, it is seen that $15 \%$ of these accidents are still unknown.

Afterwards, we classified the general causes of aircraft accidents according to 10-yearly intervals as given in Figure 2. Accordingly, it is seen in Figure 2 that mechanical accidents are the most important accidents between the years 19461956. These years are numerically followed by the years 1968-1978 and 19351945. The most interesting aspect is the possibility of the occurrence of humanrelated accidents as in the same sequence. The reason for this may be the increase in the activities of the units that will make more detailed investigations on the causes of the accident, with more emphasis on research on aircraft accident reports since the early 1990s. In Figure 3, we classified the mechanical system errors according to 10-yearly intervals. On the left-hand side of Bar Plots in Figures 2 and 
3 , the number of accidents is given while the general causes of accidents and mechanical system errors are determined at the abscissa coordinate, respectively. Accidents due to system errors are much more important than accidents due to pilotage errors in the first half of civil aviation history. As seen in Figure 3, the most common accidents in system errors are caused by engine-related accidents, and the number of accidents caused by the engine between 1946-1956 is the highest. These values coincide with the period between 1946 and 1956 when pilotage errors are the highest. The question here is how the highest increase in both mechanical and pilotage defects corresponds to the same 10-year period. We also applied annual time series analysis to the available data to make a detailed analysis according to the years.

The data used in this study were the aircraft accidents caused by humanrelated and mechanical reasons that occurred between 1918-2019 and the forecasting model was evaluated. We used the ARIMA model from the BoxJenkins methods. It was seen that the forecasting results were higher in the ARIMA $(5,1,6)$ model than the other models, and 10-yearly predictions have been made. This study aimed to analyze the time series of aircraft accidents according to years, to determine the appropriate time series model, and to make predictions future years. Firstly, we plotted aircraft accidents according to years as seen in Figure 4. Here, it can be seen that the first important increase in aircraft accidents occurred between 1925-1930 and the most serious increases have been experienced with the coming of the 1940s, which has affected the distribution seriously, as well. In addition to this, 1948 was the most accidental year with more than 200 aircraft crashes. The accidents decreased significantly in the 2010s.

These results were obtained from the original data; however, we applied some processes to become the series stationary. For example, we applied logarithmic transformation and a difference operation, and the movements of the data were randomized. These are important steps to make a correct prediction. All these applications are shown in Figure 5. In Figure 6, the auto-correlation function and partial auto-correlation function graphics were evaluated together. When we examined these graphics, it was seen that the "Data_Log_Diff" series contain both AR and MA. As a result of this analysis, it is assumed that the model with the best results was ARIMA $(5,1,6)$. The residuals of the ARIMA $(5,1,6)$ model show the normal distribution and do not have autocorrelation from the distribution graphics, 
and all autocorrelations were within the limits in the autocorrelation graph of the residues as seen in Figure 7. The dataset was divided into two groups as training and testing, and the effectiveness of the model was evaluated. The years 1918-2000 and 2001-2019 were the sets as training and test, respectively. In Figure 8, the values predicted by the model with the real data of 17 years were shown.

The 10-yearly period between 2020-2028 was estimated and the number of accidents was evaluated, and 10-yearly forecasted values were given in Table 4. It is predicted that, as in the original accident numbers, there will be both an increasing and decreasing number of aircraft accidents over the years and the highest accident will occur in 2022 and 2023. As seen in Figure 9, the deviation may be higher due to the density of the blue region from the linear prediction graph. From all these analysis results, we can predict that an important increase will be seen in the aircraft accidents for the years 2022 and 2023, and a decreasing trend will follow this increasing afterwards.

In addition, considering the locations of the accidents, it was divided into four climate zones and an appropriate time series model has been tried to determine for the accidents occurring in each zone. These zones were shown in Table 5 and the aircraft accidents according to years in the four zones were shown in Figure 10. When the time series analysis was made for four zones, it was seen that Zone 2 was separated from the others and gave meaningful results statistically. We also used the Box-Jenkins ARIMA model for these predictions. In Zone 2, a higher number of accidents occurred with a significant difference between 1957-1958. The second significant increase was seen in 1975 . However, it was seen that there was less accident in the 1980s. Theoretical model results were shown in Figures 11, 12, and 13. From these results, aircraft accidents are likely to decrease in Zone 2 between the years 2019-2023, but they are likely to increase again after the year 2023. Another decrease will follow this increase in 2027.

\section{Genişletilmiş Özet}

Havayolu taşımacılığ birçok sebepten dolayı en çok tercih edilen ulaşım türlerinden biridir. Buna karşın gelişen teknoloji ile birlikte kaza riskini en aza indirgemek için birçok kuruluş tarafindan çalışmalar ve araştırmalar yürütülmektedir. Havacılıkta kaza nedenleri olarak bilinen ve çalışmamızda da yer 
alan nedenlerin başlıcaları; insan faktörleri ve teknik nedenlerden kaynaklanan kazalardır. Havacılığın ilk yıllarında meydana gelen kazaların esas sebepleri teknik nedenlerden kaynaklanırken; gelişen teknoloji ile birlikte azalan teknik neden kaynakl1 kazalar yerini havacılık sektöründe artan insan gücünün sebep olduğu insan kaynaklı hatalardan meydana gelen uçak kazalarına bırakmıştır. Pilot, kontrolör, teknisyen gibi uçuş ve uçuş öncesinde kritik safhalarda yer alan insanların yaptıkları küçük bir hata büyük felaketlere yol açabilmektedir. Ayrıca havacılık şirketlerinin artmasıyla gelişen rekabet artışı, işletmelerin daha fazla kazanma uğruna çalışanlara aşırı yük verme eğilimde olmalarına neden olmakta ve bu da uçak kazalarındaki artışı tetiklemektedir.

Kriz, aniden ortaya çıkan, beklenilmeyen, alışılmamış, olağandışı, stresli ve travmatik bir olay sonucu gelişen heyecansal bozulma halidir. Yaşamın gelişim ve geçiş dönemlerindeki zorlanmalar (ergenlik, evlenme, doğum, sünnet, yaşl1lık, ölüm, askerlik, hastalıklar) veya raslantısal yaşam olayları (kaza, doğal afet, savaş, iş kaybı, iflâs, ekonomik zorluklar, boşanma, göç, hapislik, işkence, şiddet, taciz vs.) tetikleyici nedenler olabilir. Bilişsel ve davranışsal bozulmalar, problem çözme becerisinde azalmaya, çaresizliğe ve deorganizasyona neden olur. Anksiyete, korku, gerginlik, konfüzyon ve depresyon gelişebilir. Bilişsel (dikkat, bellek, yargı, karar, odaklanma, problem çözme), duygusal (çaresizlik, ümitsizlik, öfke, ağlama, depresyon), davranışsal (yavaşlama, içe kapanma, iştahsızlık, sinirlilik) ve psikofizyolojik (titreme, çarpıntı, bulantı, baş dönmesi, terleme) krizler ortaya çıkabilmektedir. Bahsi geçen bu krizler, uçak kazalarında insan kusurlarına bağlı kaza türünün içerisinde yer almaktadır. Bu çalışmada, sivil havacılıkta dünyada çok kabul gören ve ülkemizde de gelişmekte olan, havayolu çalışanlarının bilişsel ve davranışsal kontrollerinin yapılmasından sorumlu havacılık psikolojisi üzerine çalışan bilim insanlarımıza araştırmalarında öncü niteliğinde olacak bir istatistiksel çalışma sunulmaktadır. Aynı zamanda uçak kazalarının teknik nedenlerine de bu çalışmamızda yer verilmiş ve bu kazaların da istatistiksel analizi yapılmıştır. Çalışmamızda, uçak kaçırma, siber saldırılar ve sabotaj gibi güvenliği tehdit eden girişimler içerik dışı bırakılarak; 1918'den 2019'un sonuna kadar bahsi geçen kazalara sebep olan kusurların detaylı bir incelemesi yapılmıştır.

Bu çalışmamızda, 1918-2019 yılları arasında, 3765 tane ölümle sonuçlanan uçak kaza verisinin istatisiksel analizi yapılmıştır. İlk olarak, sistem hatalarına bağlı kazaların yüzdelik dağılımları yapılmış ve mekanik hatalar, pilotaj hataları ve 
bilinmeyen hatalar olarak sınıflandırılmıştır. Sonrasında 10 yıllık aralıklarla uçak kazalarının genel sebepleri snıflandırılmıştır. Bu sınıflandırma sonucunda yüzdelik sirayla 1946-1956, 1968-1978 ve 1935-1945 y1lları arasında kaza sebeplerinin en önemlisi olarak mekanik kazalar görülürken; aynı yıllarda insan kusurlarından (özellikle pilotaj) kaynaklanan kazalarda da aynı sırada değişim görülmüştür. Fakat sivil havacılığın ikinci çeyreğinden sonra insan kusurlarından kaynaklanan kazaların sayısında önemli bir artış göze çarpmaktadır. Özellikle 1989 yılından sonra yüksek enlemlerde kaza oranlarının artması dikkat çekicidir.

Çalışmamızda ikinci olarak geleceğe yönelik kaza olasılıkları hakkında tahmin yürütebilmek için zaman serisi analizi yapılmıştır $\mathrm{Bu}$ analiz için BoxJenkins yöntemlerinden olan ARIMA modeli kullanılmıştır. $\mathrm{Bu}$ analiz sonuçlarından kazalardaki ilk önemli artışın 1925-1930 yılları arasında olduğu tespit edilmiştir. 1948 y1lının ise 200'den fazla (ölümcül kaza) kaza sayısı ile en fazla kaza içeren yıl olduğu ortaya çıkmıştır ve 2010 y1lından sonra ise kaza oranlarının önemli ölçüde azaldığı görülmüştür.

2020-2028 yılları arasında 10'ar yıllık periyodlar için ARIMA $(5,1,6)$ sonuçlarını kullanarak geleceğe yönelik tahminleri yaptığımızda ise en yüksek kaza sayılarının 2022-2023 yılları arasında olacağı bulunmuştur. Sonrasında ise kaza oranlarında bir azalış meydana geleceği görülmüştür. Geleceğe yönelik kaza tahminlerini yaparken, Dünya üzerindeki enlemleri iklim bölgelerine göre dört bölgeye ayırarak, her bir bölgedeki kaza oranları belirlenmiştir. Bu iklim bölgelerine göre en iyi analiz sonuçlarını 12-38 derece enlemleri vermiştir. $\mathrm{Bu}$ sonuçlara gore, en fazla kazanın 1957-1958 yılları arasında yaşandığı görülmüştür. İkinci önemli artışta 1975 yılında yaşanmıştır, bunu en az kaza ile 1980 y1lı takip etmektedir. İleri ki zamanlarda, ikinci bölgede, 2019-2023 y1lları arasında kazaların düzenli olarak azalacağını, 2023 yılından sonra artacağı ve 2027 yılından sonra da tekrar azalma trendine geçeceği öngörülmüştür.

\section{Bibliography}

\section{Books}

Box, G. E., Jenkins, G. M., Reinsel, G. C. and Ljung, G. M. (2009). Stochastic models and their forecasting. England: WILEY Publishing ( $5^{\text {th }}$ Edition). 
Calderón, D.J. (2014). Aviation Investment Economic Appraisal for Airports, Air Traffic Management, Airlines and Aeronautics. England: Ashgate Publishing Limited.

Cryer, J. D. and Chan, K. S. (2008). Time-series Analysis with Applications in R, USA: Springer ( $2^{\text {nd }}$ Edition $)$.

Çetek, C., Ateş, S.S., Cavcar, A., Cavcar, M., Kayıtmaz, O. and Apaydın, M. (2016). Harekât Performans. Eskişehir: Anadolu Üniversitesi Yayınları ( $1^{\text {st }}$ ed.).

Çetingüç, M. (2016). Havacılık ve Uzay Psikolojisi. Ankara: Atlas Akademik Basın Yayın Dağıtım, Tic. Ltd. Şti ( $1^{\text {st }}$ ed.).

Doviak, R.J., Vladislav, M.D. and Zrnic, S. (1999). Aviation Weather Surveillance Systems 'Advanced Radar and Surface Sensors for Flight Safety and Air Traffic Management'. United Kingdom: The Institution of Electrical Engineers.

Evans, J.E. (2001). 'Developments in US Aviation Weather R\&D', New Concepts and Methods in Air Traffic Management in Lucio Bianco, Paolo Dell'Olmo, Amedeo R. Odoni (Eds.). Berlin: Springer.

Lucertini, M., Smriglio, S. and Telmon, D. (1997). 'Network Optımızation In Air Traffic Management', Modelling and Simulation in Air Traffic Management in Lucio Bianco, Paolo Dell'Olmo, Amedeo R. Odoni (Eds.). Berlin: Springer.

Muller, R. and Drax, C. (2014). 'Fundamentals and Structure of Safety Management Systems in Aviation' Aviation Risk and Safety Management Methods and Applications in Aviation Organizations in Roland Muller, Andreas Wittmer, Christopher Drax (Eds.). Switzerland: Springer International Publishing.

Okkay, İ. (2017). Halkla İlişskiler. İstanbul: Genel İşletme, İstanbul Gelişim Üniversitesi Yayınları.

Okkay, İ. (2019a). Kurumsal Sosyal Sorumluluk, Sosyal, Beşerî ve İdarî Bilimler Alanında Araştırma ve Değerlendirmeler. Ankara: Cilt 3, Gece Akademi Dizayn Birimi. 
Riedle, R. (2006). 'Importance of CISM in Modern Air Traffic Management (ATM)'. Critical Incident Stress Management in Aviation in Jörg Leonhardt and Joachım Vogt (Eds.). England: Ashgate Publishing Limited.

Stolzer, A.J., Halford, C.D. and Goglia, J.J. (2008). Safety Management Systems in Aviation. England: Ashgate Publishing Limited.

Wensveen, J.G. (2007). Air Transportation A Management Perspective. England: Ashgate Publishing Limited.

Yalçınkaya, A., Sarılgan, A.E., Sesliokuyucu, İ.P., Altuntaş, Ö. and Battal, Ü. (2016), Hava Kargo ve Tehlikeli Maddeler. Eskişehir: Anadolu Üniversitesi Yayınları ( $1^{\text {st }}$ ed.).

\section{Conference Articles}

Bal, F. and Okkay İ. (2019a). Eşler Arası Çatışma Boşanma Nedenleri: Medya Yansıması Sosyolojik ve Psikolojik Boyut Bir Literatür Derlemesi. $4^{\text {th }}$ International Congress on Social Sciences-Humanities and Education, Ankara.

Bal, F. and Okkay, İ. (2019b). İş Performansı Mobbing İlişkisi: Çalışanlarda Verimlilik ve Performans Üzerine Bir Derleme. $4^{\text {th }}$ International Congress on Occupational Safety and Health, Ankara.

Bal, F. and Okkay, İ. (2019c). Çalışanlarda Ücret Algısı ve Psikoloji İlişkisi: Bir Literatür Derleme Çalışması. $4^{\text {th }}$ International Congress on Occupational Safety and Health, Ankara.

Sun, Z., Ma, C., Li, W. and Shen, C. (2014). 'Flight Operations Quality Assurance Based on Clustering Analysis'. Proceedings of the First Symposium on Aviation Maintenance and ManagementVolume II in Jinsong Wang (Eds.). Berlin: Springer.

Wang, X., Xu, B., Wei, S. and Chen, L. (2014). 'Study and Analysis to the Failure Cable Plug Resulting in X-Type Airplane Engine Stopping in the Air'. Proceedings of the First Symposium on Aviation Maintenance and ManagementVolume I. Berlin: Springer. 


\section{Articles}

Atalay, A., Tortum, A. and Gökdağ, M. (2012). Türkiye'de 1977-2006 Yılları Arasında Meydana Gelen Aylık Trafik Kazalarının Zamansal Analizi. Pamukkale Üniversitesi Mühendislik Bilimleri Dergisi, 18(3), 221-229.

Mazon, J., Rojas, J., I., Lozano, M., Pino, D., Pratz, X., and Miglietta, M., M. (2018). Influence of Meteorological Phenomena on Worldwide Aircraft Accidents, 1967-2010. Meteorological Applications, 25, 236-245.

Okkay, İ. (2019b). Küreselleşen Dünyada Kriz Yönetiminin Önemi. Eurasian Journal of Researches in Social and Economics, 6(3), 308-317.

Uslu, S. and Dönmez, K. (2016). Geçmişten Günümüze Havac1lık Kazalarının Sebeplerindeki Değişimler Üzerine Bir İnceleme. The Journal of Social Sciences, 3(9), 222-239.

\section{Web Pages}

National Transportation Safety Board (2018). Günlük kaza verileri. 25 Ocak 2019 tarihinde https://www.ntsb.gov/_layouts/ntsb.aviation/index.aspx internet adresinden alınmıştır.

Plane Crash Info (2018). Günlük kaza verileri. 25 Ocak 2019 tarihinde http://www.planecrashinfo.com/database.htm internet adresinden alınmıştır. 